LinguistikTerapan 15 (2) (2018): 135-147

Jurnal Linguistik Terapan Pascasarjana

Available online http://jurnal.unimed.ac.id/2017/index.php/JLT-

Unimed

\title{
IMPROVING STUDENTS 'ACTIVITIES AND LEARNING RESULTS USING THE USED BOTTLES
}

\author{
Mulatua Lumban Gaol \\ Diterima Mei 2018; Disetujui Juni 2018; Dipublikasikan Agustus 2018
}

\begin{abstract}
This study aims to increase the students' activity and the learning result in English in learning in the procedure text only reached 61.81 . Used bottle is a tool that can be used as an appropriate English learning media to increase the students' activity and learning result in learning the procedure text. This research method is quantitative that there is the influence of used bottle learning media on student learning Result in procedure text learning. This cycle is carried out in the form of an assessment process that consists of four stages, namely: (1) planning, (2) taking action, (3) observing, and (4) reflecting. This classroom action research was carried out in three cycles. The results of the study presented include the results of tests and non-tests. Student learning result increase the pre-cycle to the first cycle, the first cycle to the second cycle, and the second cycle to the third cycle. The average value before the cycle is 61.81 (low). The average value in the first cycle is 64.31 (medium) or an increase of 2.50, the average value in cycle II is 73.33 (medium) or has an increase of 9.02, and the average value in cycle III is 83.33 (high) or an increase of 10.00 .
\end{abstract}

Keywords: activity, used bottles, procedure text, learning result, learning media

How to Cite: Gaol, Malatua Lumban (2018). Improving Students' Activities and Learning Results Using the Used Bottles..Jurnal Linguistik Terapan Pascasarjana Unimed, 15 (2): 135-147

*Corresponding author:

ISSN 2407-7410 


\section{Introduction}

Learning English at the junior high school, one of competence in English needed is listening. Students are required to master every competency contained in basic competencies so that it can be realized in daily life. Based on the experience of researchers as English teachers for a number of years teaching at school, it shows that student learning activities are still low and student learning result about procedure text. The activeness of students in doing the exercises is less eager to pay attention to learning English. Students still feel difficulty in doing the exercises given by the teacher, the lack of group work in doing the students' tasks only reaches below 50\% while the students' learning result about procedure text in 2015/2016 only reaches 61.81 , or at a sufficient level. From the determined the minimal value that is 75 , there are no students who are complete.

Of the 36 students there, all students have not been able to exceed the minimal value. The low scores obtained by students were 50 and the highest score obtained by students was 70. The state of the teacher before the cycle, the English teachers did not do apperception by raising students' activities, motivation, and learning, the teacher immediately conveyed the learning. The teacher does not explain the learning objectives so that students become less enthusiastic about learning. The teacher immediately delivered group learning. The teacher does not choose teaching materials that are in accordance with what they are taught, organizing inappropriate teaching materials, giving irregular explanations in learning scenarios, technical mismatches with learning objectives, and not having complete instruments.

Based on the description, the researcher is interested in conducting research and finding solutions on how to improve the activity and learning result of students' creativity in learning English with material Text Procedure through used bottle learning media. This used bottle learning media is the right media to increase activity and learning Result. This learning media aims to make the classroom feel more enjoyable and enthusiastic in learning. Student Learning Activities Student learning activities are all forms of activities carried out by students, especially in the learning process in class or at school. The form of activities called learning activities can vary, can be listening, recording, reading, summarizing, asking questions, answering questions, discussing, conducting experiments, etc., with which all can be known that the activity of learning is student-centered and not on the teacher.

Teachers only have a role to facilitate, teach, guide and direct, and correct and evaluate student learning Result. Teaching is an effort made by the teacher so students learn. In learning, students are the subject, so students are the actors of learning activities. Likewise in learning, so that students act as actors in learning activities, the teacher should condition learning that requires students to be active in learning activities. Some forms of effort that can be done by the teacher in developing student learning activeness in subjects are among others by increasing student interest, arousing student motivation, applying the principle of individuality of students, and using the media in learning. 


\section{Students' Learning Activity}

Jams (1996: 21) media of student learning are the main factors that determine the active involvement of students in learning. Furthermore, student learning activities relate to student attention. The difference is that student learning activities are more settled while attention is more temporary and sometimes disappears. In the student learning process, attention plays an important role.

Risk (2002: 42) in his book "No learning takes place without attention." Said the learning process will run smoothly if students have great interest that raises their attention in learning. Therefore, teachers need to raise the interest of their students so that the lessons provided are easy to understand so they are actively involved in learning.

Ibrahim (2002: 45) suggested several attempts to attract student learning activities in the teaching and learning process are influenced by the interests and needs of students, because both will be the cause of attention. Something that attracts students and is needed, will attract their attention, thus they will be serious in learning.

While Djamarah (2005: 25) suggests efforts that can be done by the teacher to arouse student activity in learning, namely:

a. Generating a need.

b. Connect with past experience issues.

c. Give the opportunity to get good results.

d. Using various forms of teaching.

Then Daradjat (2002: 26) with an editor who is not much different, mentions some effort that can be done by the teacher to activate student learning in the teaching and learning process, namely: a. Generating needs in children such as spiritual, physical, social needs, and so on. This sense of need will lead to instability, dissatisfaction that requires satisfaction. b. The experiences that you want to instill in children should be based on the experiences they already have. c. Give the opportunity to participate to achieve the desired results. Tasks must be adjusted to the ability of students. Children who have never achieved good results or never got the job done properly feel hopeless. d. Using media tools and various teaching methods.

\section{Motivation}

The teacher's job is to arouse student motivation so that he wants to learn actively. Student motivation can arise from within the individual student and can also arise due to outside influences. The motivation that arises from within students themselves without any invitation or influence from others is called intrinsic motivation. Whereas the motivation that arises due to crushing from outside the student, whether due to an invitation, an order or coercion from another person is called extrinsic motivation. In the context of learning motivation, Syaiful Bahri Djamarah and Aswan Zain put forward the following: For students who always pay attention to the subject matter provided, it is not a problem for the teacher, because in the student there is already motivation, namely intrinsic motivation. Such students usually with their own awareness pay attention to the teacher's explanation. More curiosity about the subject 
matter given. Various disturbances around him are less able to influence him to solve his attention.

Sayodih (2002: 36) says that in learning, students must have high learning motivation, both from within and outside the students. Some efforts that can be done by the teacher to arouse students' motivation and make them active in participating in learning, including:

a. Give intermediate targets. The ultimate goal of learning is to pass the exam or go to class. The final goal is only reached at the end of the year. To arouse the motive of learning, intermediate targets are held, such as semester exams, mid semester, daily tests, quizzes, and so on.

b. Creating a pleasant learning atmosphere. A warm learning atmosphere contains an atmosphere of friendship, there is a sense of humor, there is recognition of the existence of students, avoiding reproach and abuse, can arouse motives.

c. Fair competition. Competition or healthy competition can generate learning motivation. Students can compete with their own learning result or with results achieved by others. In this competition can be given praise, rewards or prizes.

Meanwhile Usman (1998:56) provides several ways to generate extrinsic motivation in fostering students' intrinsic motivation in learning, namely: a. Competition (competition): The teacher tries to create competition among his students to improve his learning achievement, trying to improve the results of previous achievements and overcome the achievements of others. b. Pace making (making a temporary or close goal): At the beginning of teaching and learning activities, the teacher should first convey to the ICT students who will be achieved so that students try to achieve the ICT. c. A clear goal: Motives encourage individuals to achieve goals. The clearer the purpose, the greater the value of the goal for the individual concerned and the greater the motivation for doing an action.

While Zain (2002:64) in the book: "Teaching and Learning Strategies" suggests six ways that can be done by the teacher in an effort to arouse students' motivation and learning passion, namely:

a. Generating encouragement for students to learn

b. Concretely explain what students can do at the end of the teaching.

c. Give rewards for the achievements of students so that they can stimulate to get better performance later on.

d. Form good habits.

e. Assist students' learning difficulties individually or in groups.

Sutikno (2001: 43) presents several strategies that can be used by teachers to foster student motivation, as follows:

a. Explain the purpose of learning to students.

At the beginning of teaching and learning, a teacher must first explain the Special Instructional Goals to be achieved by students. The clearer the goal, the greater the motivation in learning.

b. Gift

Given to the studets who get the achievement. This will spur their enthusiasm to be able to study harder. In addition, students who have not achieved will be motivated to be able to pursue outstanding students. 


\section{c. Competition / competition.}

The teacher tries to hold competition among his students to improve his learning achievement, trying to improve the results of achievements previously achieved.

d. Praise

It is appropriate for students who excel to be given awards or praise. Of course, praise is to build and arouse student learning so students have the interest and passion to learn.

e. Punishment

Punishment is given to students who make mistakes and violations during the teaching and learning process. This punishment is given in the hope that students want to change themselves and be aware so that in the next learning students try to spur learning motivation.

According to Rosita (1995: 102) "Motivation is the basic drive that moves someone to behave. This encouragement is in someone who moves to do something that is in accordance with the urge in him. In order for learning to be more quality, the teacher must be able to generate student motivation to learn, because if there is no encouragement in students to learn, the learning process will not be effective.

Students who are motivated to learn will actively participate in lessons that take place without any compulsion, but voluntarily on their own initiative. As a result of this, the learning Result achieved will increase and be absorbed longer, because with the learning motivation, the motivation in students will be fulfilled; and students will feel satisfied with learning Result that are felt as fulfilling needs. In learning activities in class there are three main things that need to be considered, namely: 1) where are students heading at the end of the activity, 2) how do students arrive at the intended target, 3) how to know whether the intended goal has been achieved or not . In order to go through these three things the teacher must create conditions that can stimulate the emergence of student learning motivation.

According to Dahar (1985:8) "Motivation functions to bind students' attention, activate the spirit of learning, provide optimal conditions for learning". Therefore, the teacher must generate student learning motivation before the learning process begins. Furthermore Ratna Wilis Dahar (1985: 8) suggested that motivation can also function to assist students in solving the problems they face, especially to find ways to achieve learning goals. In this case students are expected to be able to complete the assignments given in their groups well regarding the subject matter they learn. Students are motivated to learn and easily solve problems, tasks, and exercises given by the teacher without feeling burdened.

\section{Students' Learning Result}

According Sudjana (1999:25) learning Result are basically changes in behavior or skills in the form of knowledge, understanding, attitudes and other aspects through a series of activities of reading, observing, listening, imitating, writing, etc., as a form of individual experience with the environment. According to A. Rooyakkers (1984:13) said that: "The teaching process is conveying learning material which means carrying out several activities. The activity is of no use if it does not lead to a specific goal " 
Meanwhile, Ahmadi (1984:35) argues that learning result are the results achieved in a business, in this case the learning result business is a manifestation of student achievement that can be seen in the value of each test.

According to Cobb (2011:12) said that improving the quality of student learning is a fundamental part of every learning kara learning is the process of transferring information and experience through knowledge, expertise, behavior and attitudes which must involve internal factors namely reason, senses and emotions in addition, external factors are the environment, the atmosphere and infrastructure of learning.

Based on these descriptions, researchers conclude that students' learning result is something that is carried out by the effort carried out by students through a mental, and various other "how to" texts.

\section{Procedure Text}

Derewianka (1990) mentions that this type of procedure text tells us how something is done through a series of steps or actions. According to Anita Lie (2004: 29), "cooperative learning is not the same as just physical activity that takes place with active interaction with the environment. Learning procedure text is a type of text that is often found around us, in manuals, recipes, rules group learning. There are basic elements of cooperative learning learning that distinguishes it from group division which is done carelessly. The application of cooperative learning will provide effective results when considering the following two core principles. The first is the existence of positive interdependence. All members in the group are interdependent on other members in achieving group goals, for example completing assignments from the teacher. The second principle is individual accountability. Here each group member must have an active contribution in working together.

The steps of learning activities using used bottle learning media are as follows:

1. Students are divided into groups. Each group consists of 5 students and each group chooses one student to become the group leader.

2. Each group receives group work material consisting of: a) 14 used bottles that read about the steps on how to make apple juice, b) 14 used bottles containing pictures about how to make apple juice, and c) 1 pole used bottles which is used to hang used bottles containing pictures and steps.

3. Each group receives an explanation of the group work that must be done.

4. Each group works in hanging a bottle with a picture and the steps for making apple juice in the right order. (start working and stop after getting a signal from the teacher)

5. The group leader examines the work of other groups by referring to the slides displayed by the teacher through infocus.

6. Receive announcements of the best work and gifts.

7. Receive confirmation from the teacher about the results of group work, and improve the vocabulary and sentence patterns that are not appropriate. 


\section{Learning Media}

Understanding the media leads to something that delivers/transmits information (messages) between the source (the message provider) and the recipient of the message. Some experts give a definition of learning media. Schramm (1977: 65) suggests that learning media is a messenger technology that can be used for learning purposes. Robert Heinich (1985:6) presents the definition of medium as something that carries information between the source (source) and receiver (receiver) information. Still from the same point of view, Kemp and Dayton (1985: 3) suggest that the role of media in the communication process is as a sending device (transfer) that transmits messages from the sender to the receiver of the message or information (receiver).

According to Kemp (1986: 85) suggested several factors that are characteristic of the media, including:

1. Ability to present images (presentation)

2. Size factor; big or small

3. Color factor: black white or color

4. Motion factor: silent or moving

5. Language factors: written or oral

6. The linkage factor between picture and sound: image only, sound only, or a combination of picture and sound.

Learning media are all tools (aids) or objects used in teaching and learning activities, with a view to conveying messages (information) learning from sources (teachers and other sources) to recipients (in this case students or learning citizens). Meanwhile, Briggs (1997:56) argues that learning media is a physical means to convey learning content / materials such as books, films, videos and so on. Meanwhile, National Education Associaton (1969) revealed that instructional media is a means of communication in print and in-kind forms, including hardware technology. From the three opinions above concluded that the learning media is everything that can channel messages, can stimulate students' thoughts, feelings, and wishes so that they can encourage the creation of learning processes in students.

Brown (1973: 23) revealed that the learning media used in learning activities can influence the effectiveness of learning. In the beginning, the learning media only functioned as a teacher's tool to teach which was used as a visual aid. In line with the development of science and technology (science and technology), especially in the field of education, currently the use of assistive devices or learning media is becoming more widespread and interactive, such as the existence of computers and the internet.

The media has several functions, including:

1. Learning media can overcome the limitations of the experience possessed by students. The experience of each student varies, depending on the factors that determine the wealth of a child's experience, such as the availability of books, opportunities for travel, and so on. Learning media can overcome these differences. If students are not likely to be brought to the object directly studied, the object is brought to the students. The object in question can be in the form of real, miniature, models, and shapes of images that can be presented in audio-visual and audial ways. 
2. Learning media can go beyond the boundaries of classrooms. Many things that cannot be experienced directly in the classroom by students about an object, which is caused, because: (a) the object is too large; (b) the object is too small; (c) objects that move too slowly; (d) objects that move too quickly; (e) objects that are too complex; (f) objects that sound too smooth; (f) objects contain dangerous and high risk. Through the use of appropriate media, all objects can be presented to students.

Gagne (2006: 14) suggests that media are various types of components in the student environment that can stimulate them to learn. The term media in the field of learning is also called learning media. In the learning process, tools or media not only can facilitate the communication process but can stimulate students to respond well to all messages conveyed.

Learning media is everything that is used to convery the message and can stimulate the students' thoughts, feelings, attention, and willingness to learn so as to increase motivation, student learning result and encourage the occurrence of deliberate, purposeful, directed and controlled learning processes. Selection of the right learning media is expected to improve the quality of student learning processes, it is in line with the opinions expressed by Rivai (2002:2) about the use of teaching media in the student learning process, as follows:

a. Teaching will attract more students' attention so that they can motivate their learning.

b. Teaching materials will be more clearly defined so that the students can understand them and allow the students master them.

\section{Research Location}

This research was conducted at SMP Negeri 3 Percut Sei Tuan, which is located at Jalan Mesjid Kecamatan Percut in class VII-4 of SMP Negeri 3 Percut Sei Tuan in the second semester of the 2015/2016 academic year. The research period was carried out for more than three months starting from 4 February 2016 until 19 May 2016. The classroom action research was carried out in three cycles. Cycle I was carried out in three actions (meetings) with a time allocation of 2 x 40 minutes, cycle II was held in three meetings with a time allocation of $2 \times 40$ minutes, and cycle III was held in three meetings with an allocation of $2 \times 40$ minutes.

\section{Research Subject}

The subjects of this study were students of class VII-4 of SMP Negeri 3 Percut Sei Tuan in the second semester of the academic year 2015/2016. This research was conducted by researchers and collaborated with two English language teachers at Percut Sei Tuan 3 Junior High School. The number of students in class VII-4 was 36 people consisting of 14 men and 22 women. The researcher took the research subject of students of class VII-4 considering the characteristics tend to be more passive than the other classes and based on the learning result in the previous material was still considered relatively low. 
The implementation of this research was supported by two English teachers as partner researchers (observers) namely Mrs. Tarbiya and Mrs. Nani Walyati, especially in observing and reflecting. The selection of partners as observers in this research process is based on the consideration that the person concerned has experience in implementing CAR. The material in this study focused on the problem of the learning process, especially on students' ability to talk about procedural texts, where student activities and results in learning were still in the low category and there were still those under the minimal value. The low ability of students to say the steps and drawings of apple juice in English is due to the lack of implementation of the learning process, both in terms of the use of strategies, methods, and media.

\section{Data Collection Technique}

The data needed in this study are quantitative data and qualitative data or a combination of the two. Quantitative data is needed primarily to measure the progress of learning Result and student learning completeness related to the subject matter of learning being studied. While qualitative data is needed to measure changes in student learning behavior during the learning process in progress, such as how students' learning motivation is in class, how their participation, enthusiasm, craft, and so forth. The data collection techniques in this study were carried out through: (1) pre-tests and post-tests, (2) observations, (3) questionnaires, and (4) photos of activities in each cycle. Research procedure Classroom Action Research is a process of assessment through a system of cycles or cycles of various learning activities. Procedure

This study is a classroom action research as for the stages to be carried out in this research using media developed by Kurt Lewin as mentioned in Dikdasmen (2003:18) that the stages or commonly called cycles (rounds) consist of four components which include: (a) planning, (b) action/acting, (c) observation (observing), (d) reflecting. The study was conducted in 3 cycles. The evaluation results in the first cycle are still incomplete so it needs improvement in cycle II. Likewise, the results of the evaluation in the second cycle, the masses have not been completed so it needs improvement in cycle III. Reflection on cycle I was carried out to determine corrective steps in cycle II. Demikilan also reflection of the cycle is done to determine the steps of improvement in cycle III.

\section{Results and Discussion of Research Result}

\section{Research Result}

This research was conducted in the second semester of the 2015/2016 academic year in the two months and a half from 3 February 2016 to 19 May 2016 as many as 9 meetings which were divided into 3 cycles. Cycle I was done in three meetings, cycle II was done in three meetings, and cycle III was done three meetings which consisted of four stages, namely (1) action planning (2) action implementation, (3) observation, and (4) reflection. The research mechanism implemented in learning is the learning process in procedure text by using used bottle learning media. The focus of observation is student learning Result about procedure text. 
The collected data is quantitative data consisting of: (1) cycle I, (2) cycle II, and (3) cycle III. Observers are observers, namely action actors and their members. Observers are observers, namely action actors and their members. The observation tool is an observation sheet. Reflection is done on problem solving. Success criteria are the criteria adopted by Ridwan (2005: 13-15). Based on the activities that have been carried out in each cycle, as many as three cycles in this class action research as an effort to increase student activity and learning result in English using learning media used bottles drawn on the results report the discussion described as follows:

\section{Students' Activity in Cycle I}

The research in the first cycle have been completed from February 4, 2016 to March 3, 2016. The planning phase carried out by the researcher is to compile several research instruments to be used in action by implementing used bottle learning media in delivering procedural text learning material. The use of used bottle learning media is expected to increase activities, motivation, learning Result, and children's understanding of the material being taught. From the results of observations and data of student learning activities in the first cycle can be explained that in the aspect of assessment shows student learning activities have increased seen from students' attention to the teacher's explanation increased by $10 \%$ so that the effect on student activity is better in doing exercises, making problems/submitting problems, solving the questions made by the group itself, solving the problem/problems raised by other groups. researchers need to reflect again to find out weaknesses and shortcomings in cycle I and researchers need to improve learning in cycle II.

\section{Students' Activity in Cycle II}

The research in the second cycle have been completed starting from March 10, 2016 until April 7, 2016. The research in the second cycle have been completed starting from March 10, 2016 until April 7, 2016. The use of used bottle learning media is expected to increase activities, motivation, learning Result, and children's understanding of the material being taught. From the results of observations and data of student learning activities in the second cycle can be explained that the aspect of assessment shows student learning activities have increased seen from the attention of students to the teacher's explanation increased $20 \%$ so that the effect on student learning activities is better in doing exercises, making questions / submissions problem, able to solve problems made by his own group well, solve problems / problems proposed by other groups well, therefore the researcher still needs to do research in cycle III to get better learning activities than in cycle II and researchers give better learning, especially in the meaning and understanding of English words and train students in word for word pronunciation and make sentences so that learning activities will increase in cycle III.

\section{Students' Activity in Cycle III}

The research in the third cycle have been completed starting from April 21, 2016 until May 19, 2016. The research in the second cycle have been completed starting from March 10, 2016 until April 7, 2016. The condition and activities in the classroom 
during the learning process run smoothly as expected and the classroom situation is safe and conducive. Students already understand the true meaning of learning. Students are so active and creative to take the learning process seriously. The teacher explains the material clearly and does not forget to convey the learning objectives clearly so that some students have understood the material provided. In addition, when the teacher gives group assignments, the classroom atmosphere is still conducive. The teacher has been able to manage the class well. Seeing the condition of the class starting to be conducive, the teacher no longer gave reprimands to students.

Students begin to actively discuss with their groups and pay serious attention during the learning process. Collaborators record on the observation sheet all activities carried out by the teacher and students during the learning, starting from the initial activities to the final activities. Everything went smoothly and did not get significant obstacles. From the observations of the researchers, students no longer had difficulties in choosing the right answers about the steps and pictures of making apple juice in procedure text learning materials. This is because students have understood and understood the meaning of the command both Indonesian sentences to English and vice versa. Students are active and creative so that students without being instructed want to do the questions given and everything can run smoothly and happily.

\section{Disscussion}

\section{Value of Pre-Cycle}

Value of students before the cycle is held in the form of learning result of class VII-4 students of SMP Negeri 3 Percut Sei Tuan 2015/2016 school year about procedure text learning material has not reached the minimum value of 75 . This is because students do not understand and understand how to use bottle learning media former. This can be seen and listed in the following table:

\begin{tabular}{|c|c|}
\hline Unsur Nilai & Nilai Yang Diperoleh \\
\hline Lowest Value & 50 \\
\hline Highest Value & 70 \\
\hline Average & 61,81 \\
\hline
\end{tabular}

\section{Value of Cycle I}

The value of cycle I in the form of learning result of class VII-4 of SMP Negeri 3 Percut Sei Tuan in the 2015/2016 school year about procedure text is listed in the following table:

\begin{tabular}{|c|c|}
\hline Unsur Nilai & Nilai Yang Diperoleh \\
\hline Lowest Value & 60 \\
\hline Highest Value & 75 \\
\hline Average & 64,31 \\
\hline
\end{tabular}




\section{Value of Cycle II}

The value of cycle II in the form of learning result obtained by students of class VII-4 of SMP Negeri 3 Percut Sei Tuan in the 2015/2016 school year on procedure text shows an increase in learning result. This is listed in the following table:

\begin{tabular}{|c|c|}
\hline Unsur Nilai & Nilai Yang Diperoleh \\
\hline Lowest Value & 60 \\
\hline Highest Value & 80 \\
\hline Average & 73,33 \\
\hline
\end{tabular}

\section{Value of Cycle III}

The value of cycle III in the form of learning result of students of class VII-4 of SMP Negeri 3 Percut Sei Tuan in the 2015/2016 school year about procedure text by using used bottle learning media. In cycle III shows an increase in student results because it has reached the Miminal completeness criteria set at 75. This is seen and listed in the following table:

\section{Conclusion}

Based on the data and the criteria of success in the three cycles that were carried out it was shown that there was an increase in student activity, where the students' learning result about the procedure text, the previous average score was only 61.81 (enough). In cycle I the average value was 64.31 (enough) or increased by 2.50 in cycle I. In cycle II the average value was 73.33 (good) or increased by 9.02. In the third cycle the average value is 83.33 (good) or has an increase of 10. Student learning activities and student learning result during learning cycle I, cycle II, and cycle III increase in stages which include activity, courage, responsibility, and success. Then the researchers conclude that the actions taken have solved the problem successfully.

\section{References}

Ahmadi. 2011. Student Learning Result. Jakarta: Gramedia Library. Brown. 1973. Familiarize with Comfortable and Fun Learning, KAIFA Bandung. Cobb, J. 2011. Improving Student Learning Quality. Citra Aditya Bhakti.

Dahar, W. 1985. Motivation to Activate the Spirit of Learning. Bandung: Angkasa. Gagne. 2006. Media Stimulates Learning. Semarang: Munansir, Jakarta. Heinich, R. 1985. Learning Motivation. Yokyakarta: IKIP Yokyakarta. Ibrahim, S. 2002. Learning Media. Bandung: CV. Wacana Prima. Jams, W. 1996. Learning Media for Students. Bandung: Citra Aditya Bhakti.

Kemp, D. 1985. Classroom Action Research. Jakarta: Ministry of Education and Culture.

Risk, T. 2002. Media Education, Definition, Development and Utilization. Jakarta: Karya Grafindo Persada.

Sutikno, S. 2001. Introduction to Educational Media in the Field of Study. IKIP Ujung Pandang. 
Usman, U. 1998. Media Education, Understanding Development and Utilization, Rajawali, Jakarta. 